Original Research Paper

\title{
Pemahaman Serta Penerapan Hak dan Kewajiban Pada Anak Usia Dini (TK dan SD) Melalui Pembelajaran PPKn Di Taman Belajar Santai Dusun Bunsalak Desa Jago Kecamatan Praya Lombok Tengah
}

\author{
Rosyada Ikhwani $^{1 *}$, Nuriadi ${ }^{2}$ \\ ${ }^{\text {I} P r o g r a m ~ S t u d i ~ P e n d i d i k a n ~ G u r u ~ S e k o l a h ~ D a s a r, ~ F a k u l t a s ~ K e g u r u a n ~ d a n ~ I l m u ~ P e n d i d i k a n, ~ U n i v e r s i t a s ~ M a t a r a m, ~}$ \\ Mataram, Indonesia \\ ${ }^{2}$ Program Studi Bahasa Inggris, Fakultas Keguruan Dan Ilmu Pendidikan, Universitas Mataram, Mataram, \\ Indonesia.
}

DOI: https://doi.org/10.29303/jpmpi.v3i2.555

Sitasi: Ikhwani, R., \& Nuriaadi (2021). Pemahaman Serta Penerapan Hak dan Kewajiban Pada Anak Usia Dini (TK dan SD) Melalui Pembelajaran PPKn Di Taman Belajar Santai Dusun Bunsalak Desa Jago Kecamatan Praya Lombok Tengah. Jurnal Pengabdian Magister Pendidikan IPA, 4(1)

\section{Article history}

Received: 15 Desember 2020

Revised: 28 Desember 2020

Accepted: 07 Januari 2020

*Corresponding Author: Rosyada Ikhwani, Program Studi Pendidikan Guru Sekolah Dasar, Fakultas Keguruan dan Ilmu Pendidikan, Universitas Mataram, Mataram, Indonesia Email:

rosyadaikhwani18@gmail.com
Abstract: Pendidikan Pancasila dan Kewarganegaraan atau yang biasa disingkat dengan PPKn merupakan salah satu mata pelajaran yang terdapat didalam kurikulum 2013. Mata pelajaran PPKn memuat berbagai materi mulai dari materi tentang politik, hukum, pendidikan karakter, hingga materi pengetahuan akan kebangsaan. Materi yang termuat didalam mapel PPKn selalu berkaitan dengan kehidupan sehari-hari salah satunya yaitu pendidikan karakter yang penting bagi peserta didik. Untuk mengajarkan materi tersebut dapat digunakan berbagai cara atau metode, salah satu diantaranya yaitu menggunakan metode kontekstual, metode kontekstual adalah metode yang menghubungkan materi pelajaran dengan keadaan atau kondisi sebenarnya yang ada dilingkungan sekitar atau di lingkungan sehari-hari peserta didik. Pendidikan karakter sangat penting untuk dikembangkan terutama untuk anak-anak yang berada didaerah kecil atau anak-anak yang berada di desa, salah satunya untuk mengajarkan mereka akan niai-niai moral yang berkembang dimasyarakat juga mengembangkan dan mempertahankan nilai-nilai spiritual yang baik dan yang diturunkan oleh orang tua mereka. Untuk bisa mencapai hal tersebut diperlukan metode pembelajaran yang tepat, sehingga tujuan yang sudah direncanakan dapat tercapai dengan baik. Dalam hal ini penggunaan metode kontekstual dalam pembelajaran PPKn terutama mengenalkan hak dan kewajiban dilingkungan masyarakat, keluarga, dan sekolah pada peserta didik cukup efektif. Hak dan kewajiban telah termasuk didalam pendidikan karakter. Diharapkan dengan pelaksanaan pembelajaran PPKn ini dapat membuat peserta didik kelak bisa menjadi generasi penerus bangsa yang pandai dan cerdas tidak hanya pada aspek kognitif namun juga pada aspek afektif mereka, Sehingga bisa membangun bangsa dan negara.

Keywords: Pendidikan PPKn; Metode Kontekstual; Pendidikan Karaker; Hak dan Kewajiban; Dusun Bunsalak 


\section{Pendahuluan}

Pendidikan PPKn (Pendidikan Pancasian dan Kewarganegaraan) merupakan mata pelajaran yang ada didalam kurikulum 2013, mata pelajaran ini salah satunya memuat pembeajaran akan nilainilai etika dan moral atau cara berperilaku ditengah-tengah masyarakat dan di berbagai jenis lingkungan, baik di lingkungan masyarakat, rumah juga yang tidak kalah penting bagi peserta didik adalah di lingkungan sekolah. Lingkungan sekolah merupakan tempat peserta didik menuntut ilmu pengetahuan sekaligus mulai belajar untuk bisa bersosialisasi dengan teman sebaya serta dengan para guru (orang dewasa) selain orang tua mereka di sekolah untuk itu penting bagi anak sebagai seorang peserta didik, anggota keluarga serta anggota masyarakat memahamai akan hak serta kewajibannya.

Hak dan kewajiban merupakan sesuatu yang penting untuk dipelajari untuk kemudian diterapkan, pada zaman ini banyak remaja yang memiliki krisis moral dalam dirinya, salah satu penyebabya ialah pada masa kanak-kanak mereka minim mempelajari akan hak serta kewajiban. Contoh krisis moral pada zaman sekarang seringkali kita lihat di media massa, ada beberapa anak yang terlibat kasus kekerasan, tawuran dan lain sebagainya. Penyebab maraknya terjadi kasus tersebut adalah karena kurangnya pemahaman akan nilai moral pada diri anak, mereka tidak memahami akan kewajiban mereka dalam menjaga keamanan dan ketertiban serta cenderung untuk menuntut hak mereka untuk diakui eksistensinya oleh teman sebaya.

Pembelajaran PPKn merupakan salah satu cara yang tepat untuk mengenalkan apa saja hak serta kewajiban anak ditengah lingkungan pergaulan serta dikehidupan keseharian mereka. Di Indonesia sendiri perkembangan moral anak merupakan sesuatu yang sangat penting untuk diperhatikan, terutama di era globalisasi seperti sekarang, mengikuti perkembangan zaman problematika yang dihadapi oleh anak juga akan semakin kompleks. Pada era globalisasi perkembangan teknologi juga semakin meningkat pesat, anak-anak usia dini bahkan bisa dengan bebas mengakses informasi-informasi dari berbagai belahan dunia tanpa bisa disaring oleh diri mereka sendiri. Banyak contoh konten yang ada diinternet, seperti konten kekerasan dan konten negatif lainnya yang bisa diakses dengan mudah oleh anak dibawah umur.

Untuk mencegah anak-anak di dusun Bunsalak mendapat dampak negatif dari adanya perkembangan teknologi serta untuk mengisi waktu luang mereka di luar jam sekolah dan di kala libur semester dengan kegiatan yang positif, maka taman belajar santai yang ada di dusun Bunsalak merupakan salah satu tempat yang bisa dimanfaatkan untuk melaksanakan berbagai kegiatan positif tersebut, seperti anak-anak bisa belajar sambil bermain, belajar bersosialisasi, berkreasi dan berbagai macam kegiatan positif lainnya.

Program mengajar mata pelajaran PPKn di dusun Bunsalak yang tepatnya dilakukan di taman belajar santai tersebut penting untuk dilakukan, karena tidak semua anak masih mau belajar dikala waktu libur maupun diluar jam sekolah. Masa kanakkanak merupakan suatu masa yang lebih banyak dihabiskan untuk bermain, anakanak tidak suka jika harus dibebankan dengan tugas-tugas atau bahkan oleh aturanaturan. Ini disebabkan karena anak-anak masih kurang memahami pentingnya tugas serta aturan-aturan yang ada, baik itu dilingkungan sekolah, rumah, dan masyarakat.

Anak-anak cenderung akan menilai bahwa aturan tersebut tidak akan memberikan dampak atau efek bagi dirinya. Pembelajaran PPKn disamping untuk menekankan nilai-nilai sosial mapel ini juga bisa digunakan untuk menekankan nilai-nilai agama, didalam mata pelajaran PPKn terdapat penjelasan mengenai dasar negara yaitu pancasila, tepatnya pada sila pertama yang berbunyi " ketuhanan yang maha esa", karena itulah selain mengajarkan akan nilai moral dalam hal ini hak dan kewajiban dilingkungan masyarakat, pada kegiatan desa mengajar di dusun Bunsalak ini juga diajarkan meneganai nilai-nilai religi seperti solat berjamaah dan mengaji bersama.

\section{Metode}

\section{a. Waktu dan Tempat}

Program ini dilakukan di dusun Bunsalak desa Jago kecamatan Praya Nusa Tenggara Barat pada bulan November 2020 s/d Januari 2021.

\section{b. Alat dan Bahan}

Alat dan Bahan yang digunakan dalam program desa mengajar ini antara lain, spidol, tinta 
spidol, papan tulis, dan peralatan mengajar lainnya yang dapat membantu berjalannya proses pembelajaran dengan lancar. Alat dan bahan yang digunakan selalu bertambah seiring berjalannya waktu, contohnya buku dan pulpen yang digunakan sebagai reward/hadiah bagi peserta didik yang dapat menjawab soal.

\section{c. Bentuk Kegiatan}

Bentuk kegiatan dalam Program Mengajar di Taman Belajar Santai dusun Bunsalak desa Jago, dengan materi PPKn hak dan kewajiban diantaranya sebagai berikut 1) kunjungan ke kantor desa Jago untuk mengantarkan surat tugas, sekaligus meminta izin untuk melaksanakan program desa mengajar 2) melakukan observasi dilokasi tempat mengajar didusun Bunsalak 3) perkenalan dengan anak-anak di taman belajar dusun Bunsalak 4) sosialisasi program dan persiapan mengajar di taman belajar santai dusun Bunsalak 5) mengajar mata pelajaran PPKn di taman belajar santai dusun Bunsalak 6) melakukan kegiatan religi atau keagamaan bersama dengan anak-anak di taman belajar dusun Bunsalak 8) melakukan lomba cerdas cermat bersama anakanak didusun Bunsalak 9) mengadakan acara perpisahan pada akhir program mengajar.

\section{d. Metode}

Pada program desa mengajar ini digunakan metode observasi, metode observasi ini berupa pengamatan terhadap peserta didik sejauh mana perkembangan mereka dalam memahami dan menerapkan materi hak dan kewajiban yang telah mereka dapatkan, pengambilan data pada metode observasi ini menggunakan teknik Pengamatan terhadap peserta didik, pengamatan Terhadap interaksi mereka dengan sesama rekan sebaya, orang yang lebih tua dan pengamatan terhadap nilai religius mereka.

\section{Hasil dan Pembahasan}

Program mengajar di desa yang dilaksanakan di dusun Bunsalak desa Jago kecamatan praya kabupaten Lombok Tengah dalam rangka mengisi waktu luang peserta didik dikala libur semester dan mengembangkan aspek kognitif serta afektif yang telah ada pada diri mereka. Terutama aspek afektif yang mereka terapkan dalam bermasyarakat. Seperti hak dan kewajiban mereka dalam lingkungan masyarakat, sekolah, dan lingkungan keluarga. Kegiatan ini dilakukan secara terstruktur, dengan melibatkan pihak kantor desa Jago juga anakanak dusun Bunsalak mulai dari anak usia TK hingga anak usia SD. Pada program ini juga melibatkan partisipasi dari masyarakat desa Jago, salah satunya yaitu warga dusun Bunsalak yang memiliki taman belajar santai dusun Bunsalak.

Taman belajar santai sendiri merupakan rumah penduduk yang disulap menjadi tempat anak-anak usia sekolah mulai dari TK hingga SD untuk belajar sambil bermain, didalamnya terdapat berbagai fasilitas seperti buku-buku pelajaran, mulai dari buku pengetahuan umum, komik, majalah anak, hingga kamus bahasa Inggris, kamus bahasa Arab dan KBBI (Kamus Besar Bahasa Indonesia). antara lain:

Rangkaian program mengajar di desa Jago

\section{Mengajar materi PPKn (hak dan kewajiban) kepada anak-anak ditaman belajar santai dusun Bunsalak}

- Pengantaran surat izin KKN kepada pihak desa Jago sekaligus survei/observasi lokasi

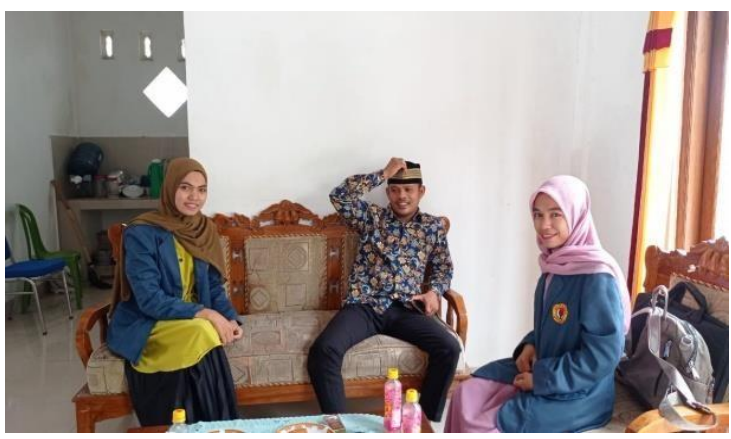

Gambar 1. Penyerahan suarat pengantar KKN

Kegiatan awal ialah meminta izin pada pihak desa, terutama kepada kepala desa Jago agar bisa menyelenggarakan program KKN desa mengajar di daerah tersebut, kegiatan ini juga dibarengi dengan menjelaskan apa saja program mahasiswa selama melakukan Kuliah Kerja Nyata (KKN) di daerah tersebut. Kepada kepala desa Jago mahasiswa program KKN menjelaskan tentang program mengajar didesa, tentang apa saja yang dibutuhkan oleh mahasiswa agar program yang akan dijalankan berjalan sesuai rencana. Setelah kegiatan dikantor desa, kegiatan selanjutnya ialah melakukan kegiatan 
observasi/survei lokasi mengajar di dusun Bunsalak.

Lokasi taman belajar santai di dusun Bunsalak terletak tidak terlalu jauh dari kantor desa Jago. Tujuan mahasiswa ke taman belajar Bunsalak tidak hanya untuk mensurvei lokasi namun juga untuk meminta izin kepada pemilik taman belajar santai untuk melakukan kegiatan mengajar di taman belajar tersebut. Ditaman belajar tersebut mahasiswa menemui ibu pemilik taman belajar untuk menyampaikan tujuan utama mahasiswa.

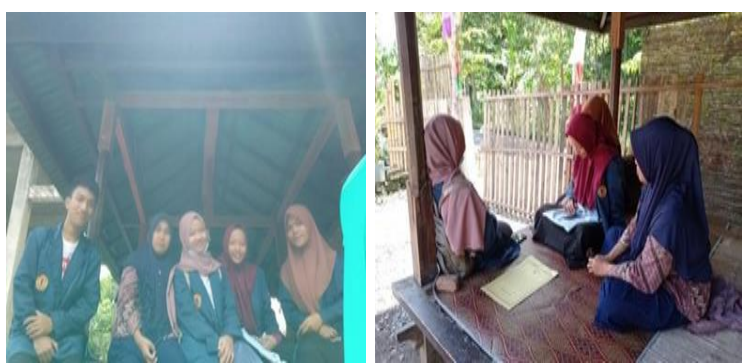

Gambar 2. Survei lokasi taman belajar

\section{Sosialisasi program desa mengajar dan} kegiatan perkenalan dengan anak-anak dusun Bunsalak

Sosialisasi program KKN bertujuan untuk memperkenalkan program kerja mahasiswa mulai dari rencana, tahapan, dan hasil pelaksananaan program kepada kepala desa, staf desa, juga beberapa kadus dan beberapa tamu undangan yang hadir. Tujuan nya ialah agar seluruh masyarakat desa Jago mengetahui program KKN yang akan dilaksanakan oleh mahasiswa sehingga diharapkan masyarakat dapat mendukung serta membantu berjalannya program tersebut, dalam hal ini program desa mengajar.

Program desa mengajar merupakan salah satu program Kuliah Kerja Nyata yang diprogramkan bagi mahasiswa Fakultas Keguruan dan Ilmu Pendidikan Universitas Mataram, program ini berisi kegiatan mengajar dan membantu staf pengajar dalam mendidik, dan menyalurkan ilmu pengetahuan diberbagai wiayah desa yang ada di Nusa Tenggara Barat untuk menumbuhkan SDM pada generasi muda yang berada diwilayah tersebut.

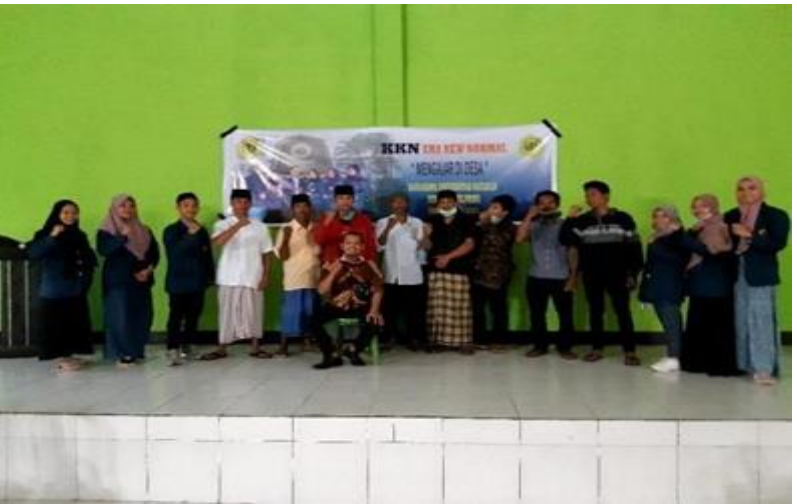

Gambar 3. Sosialisasi Program Mengajar

Setelah melakukan kegiatan sosialisasi pengenalan program kerja, kegiatan selanjutnya ialah melakukan perkenalan dengan siswa taman belajar santai dusun Bunsalak, acara perkenalan dilakukan di taman belajar santai. Kegiatan ini penting untuk dilakukan agar keakraban antar pendidik dan peserta didik dapat terjalin dengan baik, bahkan ada pepatah yang mengatakan bahwa "tak kenal maka tak sayang", demi berjalannya kegiatan pembelajaran dengan lancar pendidik harus bisa dan berusaha untuk mengakrabkan diri dengan peserta didik.

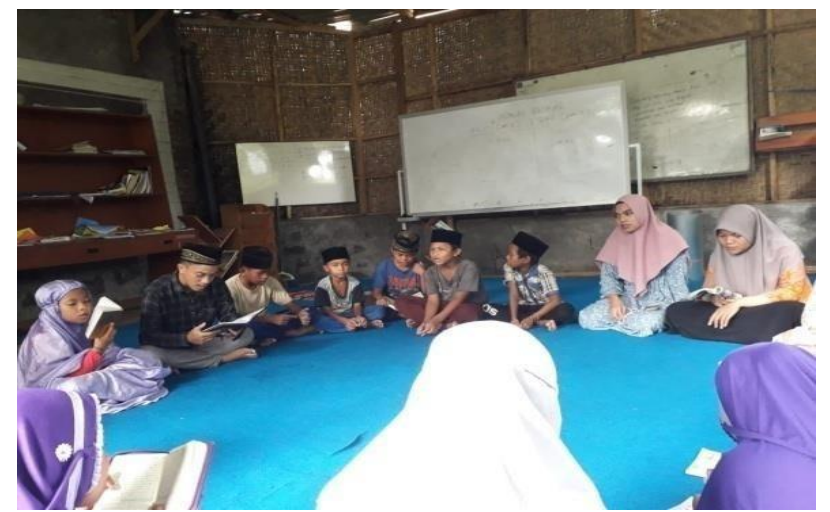

Gambar 4. Kegiatan Perkenalan dengan Peserta Didik

\section{Kegiatan Pembelajaran PPKn sekaligus} Pembelajaran keagamaan (Religi)

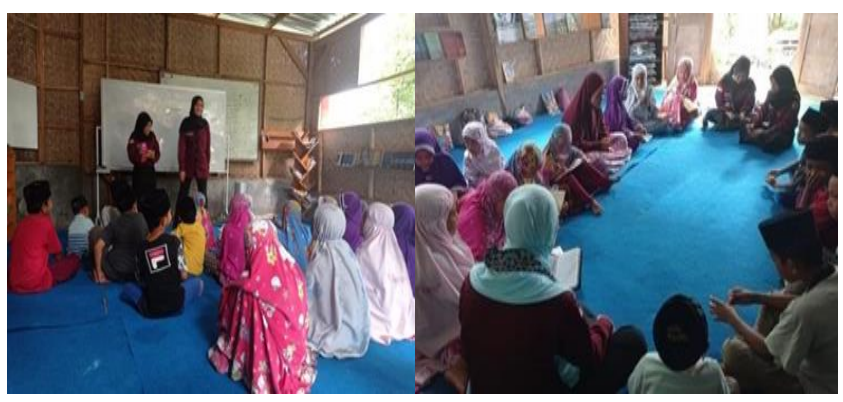

Gambar 5.Belajar dan Mengaji 
Kegiatan pembelajaran dan mengaji dilakukan secara berurutan, sebelum kegiatan pembelajaran dimulai, peserta didik beserta mahasiswa menjaankan kegiatan solat berjamaah sekaligus mengaji bersama, ini merupakan salah satu contoh penerapan nilai-nilai moral, dalam hal ini kewajiban bagi seorang manusia sebagai hamaba Allah, tuhan yang maha esa.

Ilmu dunia harus berjalan beiringan dengan ilmu akhirat, ini disebabkan tanpa adanya pengetahuan akan ilmu akhirat, manusia bisa saja berbuat suatu hal yang keji dengan ilmu pengetahuan yang mereka miliki, dalam hal ini ilmu pengetahuan dunia. Banyak contoh kasus yang kita temui atau kita lihat dalam kehidupan seharihari bagaimana seorang yang berilmu seringkali berperilaku dzalim terhadap sesamanya, seperti koruptor.

Koruptor adalah orang yang berpendidikan dan memiliki ilmu namun tidak memiliki ilmu agama. Mereka tidak takut untuk berbuat kejahatan. Untuk mencegah generasi muda melakukan hal yang dilakukan oleh para koruptor maupun oleh orang yang bertindak jahat dengan memanfaatkan ilmu yang mereka miliki, maka pendidikan PPKn serta agama perlu untuk diberikan kepada peserta didik. Agar kelak mereka bisa menjadi penerus bangsa yang cerdas dan amanah.

\section{Kegiatan Lomba}

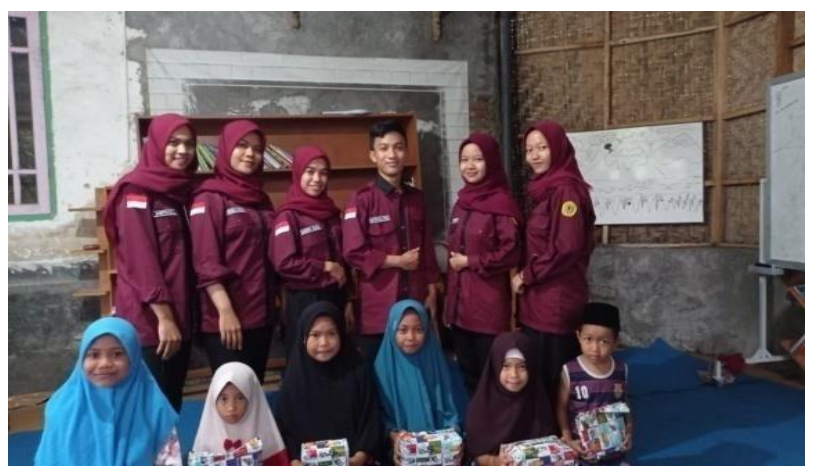

Gambar 6. Pembagian hadiah lomba

Kegiatan lomba diadakan untuk melatih jiwa sportifitas, kebersamaan dan kerjasama peserta didik sekaligus melihat sejauh mana pengetahuan siswa akan materi yang telah mereka dapatkan selama mengikuti kegiatan pembelajaran di taman belajar santai dusun Bunsalak. Karena taman belajar santai mengusung tema belajar sambil bermain, maka kegiatan yang dilakukan pun tidak hanya belajar dan belajar saja, namun diselingi juga dengan aktivitas lainnya yang dapat meningkatkan semangat dan motivasi peserta didik dalam belajar salah satunya yaitu berpartisipasi dalam mengikuti lomba, baik itu lomba akademik maupun non akademik.

Pada dasarnya anak usia TK maupun anak usia sekolah dasar (SD) selalu ingin bermain, waktu mereka paling banyak mereka habiskan untuk bermain. Oleh sebab itu, agar anak bisa bermain tanpa kehiangan waktu untuk belajar, guru dan orang tua harus memahami bagaimana metode yang tepat untuk mengajarkan anak pada usia dini mengenai ilmu pengetahuan.

Salah satu metode yang dapat digunakan ialah metode belajar sambil bermain, yaitu dengan menyelipkan materi pelajaran ke dalam permainan anak. Contohnya permainan menyusun puzzle atau permainan tebak-tebakan dapat melatih memori atau ingatan anak akan suatu ilmu pengetahuan tertentu. Selain melakukan kegiatan perlombaan, kegiatan yang dapat melatih ingatan siswa ialah melakukan senam. Senam dapat melatih ingatan serta saraf motorik anak.

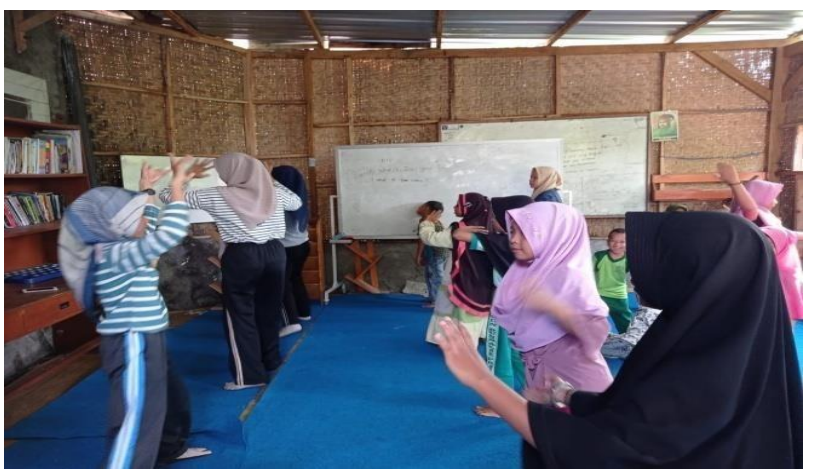

Gambar 7. Senam Pagi

Semua kegiatan di atas melatih siswa dalam bersosialisasi dilingkungan masyarakat. Secara tidak langsung rangkaian kegiatan mulai dari belajar, melakukan kegiatan ibadah, lomba, senam (Olahraga) melatih anak-anak untuk mengenal hak dan kewajiban mereka. Contohnya mereka memiliki kewajiban untuk menuntut ilmu, kemudian mereka mendapatkan haknya berupa reward/hadiah ketika memenangkan lomba cerdas cermat. Selain itu mereka juga menerima haknya untuk mendapatkan pendidikan dimanapun dan kapanpun, tidak hanya di sekolah.

\section{Perpisahan dengan peserta didik taman belajar santai dusun Bunsalak desa Jago}


Acara perpisahan ini diselenggarakan ditaman belajar santai diikuti oleh para peserta didik serta mahasiswa program KKN. Acara ini bertujuan untuk meluangkan waktu terakhir untuk berkumpul dengan peserta didik sebelum mahasiswa KKN selesai menjalankan programnya.

Rangkaian acaranya yaitu, kejutan yang diberikan oleh peserta didik kepada mahasiswa berupa kue dan ruangan yang telah di hias sedemikian rupa juga tidak lupa peserta didik meberikan kartu ucapan terimkasih kepada mahasiswa KKN yang telah membimbing serta mengajarkan mereka berbagai ilmu pengetahuan. Dari hal ini bisa dilihat bahwa mereka, peserta didik ditaman belajar santai memiliki kecerdasan afektif. Terbukti dengan usaha mereka dalam menunjukkan kasih sayang kepada orang yang lebih dewasa dari diri mereka, dengan menyiapkan kejutan yang tidak diduga sebelumnya oleh mahasiswa. Dari hal ini mahasiswa dapat menilai perkembangan kemampuan afektif mereka terutama pemahaman tentang kewajiban serta hak pada diri mereka dalam bermasyarakat. Yaitu tentang Peserta didik wajib menghormati orang yang lebih tua dan kemudian peserta didik(anak-anak) berhak untuk mendapatkan cinta dan kasih sayang.

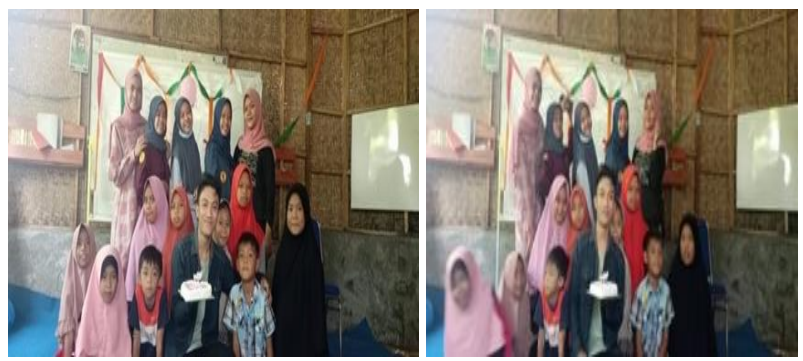

Gambar 8. Acara Perpisahan

\section{Kesimpulan}

\footnotetext{
Berdasarkan hasil yang didapat dari kegiatan mengajar didesa dengan fokus pembelajaran PPKn yaitu mengenai hak dan kewajiban, setelah melakukan observasi dapat ditarik kesimpulan bahwa rata-rata anak atau peserta didik yang mengikuti kegiatan pembelajaran di taman belajar santai dusun Bunsalak telah memahami hak serta kewajibannya sebagai anak, peserta didik juga sebagai anggota masyarakat. Terbukti dari setiap tingkah, sikap dan perilaku mereka yang sering kali ditunjukkan. contohnya seperti selalu mengerjakan tugas yang
}

diberikan dengan baik dan tekun, selalu menyayangi sesama dan bermain bersama teman sebaya dengan cara yang baik. Selalu mendengarkan perkataan atau nasihat orang yang lebih tua. Ini membuktikan anak-anak dusun Bunsalak memiliki kemampuan bersosialisasi yang baik juga mampu menerapkan setiap materi yang telah diberikan kepada mereka, yaitu materi tentang hak dan kewajiban.

\section{Ucapan Terima Kasih}

Terimakasih kepada FKIP Universitas Mataram, kemudian terimakasih juga kepada DPL kami yaitu Bapak Dr. H. Nuriadi,SS., M.Hum dan terakhir terimakasih juga kepada mitra kami yaitu pemilik taman belajar santai dusu Bunsalak desa Jago terkhusus pada kepala desa Jago beserta staff desa. Karena Atas bantuan dan bimbingannya, KKN Terpadu 2020 Program Mengajar di Desa di Era New Normal ini dapat berjalan dengan lancar.

\section{Daftar Pustaka}

Ibda, F. (2012). Pendidikan moral anak melalui pengajaran bidang studi PPKn dan pendidikan agama. JURNAL ILMIAH DIDAKTIKA: Media Ilmiah Pendidikan dan Pengajaran, 12(2).

Dianti, P. (2014). Integrasi Pendidikan Karakter dalam pembelajaran Pendidikan Kewarganegaraan untuk mengembangkan karakter siswa. Jurnal Pendidikan Ilmu Sosial, 23(1).

Winarno, M. S. Muatan Karakter dalam Materi Pendidikan Kewarganegaraan (Studi kasus pada buku pelajaran PPKn SMA). 